\title{
MENINGKATKAN MUTU PENDIDIKAN MELALUI (STRAPENASDI) STRATEGI PENDEKATAN ADMINISTRASI SUPERVISI PENDIDIKAN
}

Fania Melinda

\author{
Email: faniamelindaa18@gmail.com
}

\begin{abstract}
ABSTRAK
Peningkatan mutu pendidikan merupakan suatu langkah awal untuk mencapai perbaikan dunia pendidikan yang lebih maju.Dalam meningkatkan mutu pendidikan seorang guru harus mampu mendongkrak kemajuan dan perkembangan teknologi dalam proses pembelajaran, sehingga seorang pendidik harus mempunyai strategi agar tujuan utama dalam meningkatkan mutu pendidikan dicapai dengan pasti dan nyata tanpa adanya wacana belaka.Ada beberapa strategi pendekatan yang mampu dilakukan oleh seorang guru dalam meningkatkan mutu pendidikan diantaranya;(1)Melalui Perencanaan peningkatan mutu pendidikan yang ada disekolah yang disesuaikan dengan visi misi dari sekolah.(2)Mengimplementasikan program peningkatan mutu yang telah direncanakan (3).Melakukan Pengawasan untuk mengetahui tingkat keberhasilan dari peningkatan mutu pendidikan itu sendiri (4).Melakukan evaluasi terhadap ketercapaian proses peningkatan mutu pendidikan.Untuk meningkatkan mutu pendidikan tersebut kita membutuhkan seorang supervisor.Tugas dari seorang supervisor adalah mendorong kepercayaan diri yang ada pada seorang guru bahwasanya proses dari belajar mengajar itu harus dapat diperbaiki.
\end{abstract}

\section{Kata Kunci :Strategi,Peningkatan Mutu dan Supervisi Pendidikan}

\section{PENDAHULUAN}

Pendidikan merupakan suatu hal yang lumrah yang harus dijalani oleh setiap orang agar bisa mencapai cita-cita masa depan yang diinginkan.Indonesia telah mencanangkan program pendidikan wajib belajar 9 tahun,namun sangat disayangkan pendidikan ini nyatanya masih saja mendapatkan kritikan yang tajam dari berbagai pihak,baik itu dari cara atau bentuk proses dari pendidikan itu sendiri hingga ketercapaian peserta didik dalam menerima pembelajaran yang telah diberikan.Indonesia sangat menjunjung tinggi pendidikan,sehingga Program pendidikan yang luar biasa ini diharapkan mampu melahirkan generasi penerus bangsa yang kreatif dan inovatif.Seiring derasnya perkembangan tantangan global yang signifikan,mengakibatkan terjadi tantangan pada dunia pendidikan yang semakin besar.Tantangan global yang semakin besar ini akan menimbulkan problematika bangsa mengenai pendidikan. Hal ini menunjukan Indonesia harus mempunyai Strategi khusus dalam meningkatkan Mutu pendidikan,sehingga akan mudah bagi bangsa indonesia dalam mencapai kemajuan pendidikan.

Mutu pendidikan berkaitan erat dengan keprofesionalan guru dalam menghadapi suatu permasalahan yang ada dalam lingkup pendidikan saat ini maupun pendidikan dimasa mendatang.Untuk dapat meningkatkan kemampuan dalam mencapai mutu pendidikan yang baik, seorang guru harus mampu untuk memperhatikan sistem dari pendidikan itu secara baik. Hal ini dapat diwujudkan melalui suatu sistem yaitu supervisi pendidikan,tugas dari seorang supervisor adalah untuk membantu,mendorong kemudian memberikan keyakinan kepada guru bahwa proses belajar mengajar harus diperbaiki.Dalam menyelenggarakan supervisi pendidikan tersebut seorang supervisor selain mendorong keyakinan kepada guru juga harus mampu memberikan makna penting terkait dengan 3 aspek Tut Wuri Handayani yaitu (1)Seorang Guru harus mampu menjadi seorang suri tauladan yang baik (2)Seorang guru harus mampu memberikan semangat agar dapat 
menggali potensi yang dimilikinya (3)Guru mampu memberikan bimbingan dan arahan kepada siswanya dari belakang.Dengan demikian,seorang guru memerlukan strategi atau acuan dalam menjalankan proses pembelajaran untuk meningkatkan mutu pendidikan.

Berdasarkan Latar belakang diatas diperoleh rumusan masalah yaitu (1).Apa Penyebab rendahnya mutu pendidikan? (2).Apa Strategi pendekatan administrasi pendidikan dalam meningkatkan mutu pendidikan? Dengan rumusan masalah diatas diperoleh suatu tujuan diantaranya: (1).Mendeskripsikan Penyebab Rendahnya Mutu Pendidikan (2).Mendeskripsikan Strategi pendekatan dari Supervisi pendidikan

\section{PEMBAHASAN}

\section{Penyebab Rendahnya Mutu Pendidikan}

Di Indonesia berdasarkan pada kenyataan yang ada,Tingkat kualitas sumber daya manusia masih sangat jauh tertinggal.Banyak Ketenagakerjaan yang ada di negeri kita yaitu Indonesia masih menghadapi masalah yang signifikan diantaranya:Angka pengangguran yang selalu membludak.Banyak kita saksikan orang yang lulus dari pendidikan masih saja pengangguran,karena tingkat kualitas SDM yang tidak mampu mengolah fikiran dan tenaganya agar mampu membuka lapangan pekerjaan, sehingga hal ini menjadi masalah yang tak henti-hentinya.Indonesia memiliki jumlah tenaga kerja yang sangat banyak yang kekuatannya itu sendiri berada pada tenaga kerja dengan spesifikasi tidak terlatih maupun yang tidak terdidik. Tenaga kerja yang ada di Indonesia telah tersebar dalam berbagai cabang sector pekerjaan .Semua para pekerja berada sesuai tingkat latar belakang pendidikan yang dimiliki.Dalam widodo (Widodo, 2016) diungkapkan bahwasanya ada beberapa pengelompokan tenaga kerja diantaranya: 1)Tenaga kerja yang terdidik;artinya tenaga kerja ini memiliki keahlian atau kemahiran yang handal dalam bidang tertentu yang dikuasainya yang didapatkan secara pendidikan formal ataupun nonformal. 2)Tenaga kerja yang terlatih 3)Tenaga kerja yang tidak terdidik dan tidak terlatih.

Penyebab dari rendahnya mutu pendidikan adalah Rendahnya Kualitas Pendidik atau pengajarnya bahkan rendahnya prestasi dari siswanya ,contoh singkatnya oleh Sabandi (Sabandi, 2013) yaitu Rendahnya Prestasi belajar siswa berkaitan dengan pengelolaan pembelajaran yang dilakukan oleh seorang guru dimana pengelolaan tersebut ternyata sangat lemah dan rendah.Salah satunya terjadi pada proses pembelajaran yang dilakukan oleh guru matematika pada umumnya karena buruknya pembelajaran matematika itu didasari pada rendahnya kualitas dari seorang guru matematika.Oleh karena itu ,peningkatan dari kualitas tenaga pendidik sangat dibutuhkan sekali dan jadi prioritas utama agar mutu pendidikan berjalan baik.

\section{Strategi pendekatan Administrasi Supervisi Pendidikan}

Strategi pendekatan Supervisi merupakan acuan kemajuan dalam mengembangkan suatu peningkatan mutu pendidikan itu sendiri.Sebenarnya ada beberapa keuntungan tersendiri yang diperoleh dari pendekatan supervisi diantaranya supervisi klinis,supervisi diferensiabel,supervisi pengembangan dan lainnya sehingga diperoleh keuntungan yaitu:Supervisi merupakan suatu proses yang menggabungkan beberapa model pendekatan secara fleksibel sehingga mampu mengembangkan model baru yang ada (Sabandi, 2013).

Ada beberapa strategi pendekatan yang dapat dilakukan untuk memajukan mutu pendidikan kedepannya oleh (Bahrun, marniati, 2017) yaitu 1) Perencanaan peningkatan mutu pendidikan yang ada disekolah yang disesuaikan dengan visi misi dari sekolah. 2) Mengimplementasikan program peningkatan mutu yang telah direncanakan 3).Melakukan Pengawasan untuk mengetahui tingkat keberhasilan dari peningkatan mutu pendidikan itu sendiri,Pengawasan disini dapat dilakukan 
secara berkala sehingga strategi tersebut terlihat berjalan dengan baik melalui pengawasan tersebut.Supervisor senantiasa harus melakukan (monitoring) dan pengawasan(Supervisi) terhadap pelaksanaan secara rutin yang harus diperbaiki.Dalam (Bambang Ismanto, n.d.) Pengawasan melekat pada diri seorang supervisor baik itu Built in control dan Function control 4). Melakukan evaluasi terhadap ketercapaian proses peningkatan mutu pendidikan.Hal ini dilakukan agar setiap pelaksanaan evaluasi dapat kita ketahui tingkat ketercapaian dari program yang telah direncanakan.Pelaksanaan evaluasi ini bisa dilakukan dengan mengacu pada program pengendalian mutu dan juga pedoman evaluasi dari pendidikan itu sendiri.

\section{PENUTUP}

\section{KESIMPULAN}

Mutu pendidikan merupakan Salah satu Tolak Ukur kemajuan suatu bangsa,mutu pendidikan yang baik akan membantu terciptanya sumber daya manusia yang lebih maju.Untuk meningkatkan mutu pendidikan bisa dilakukan kegiatan supervisi pendidikan yaitu membantu meningkatkan kegiatan proses belajar mengajar guru dikelasnya dan dilaksanakan secara terprogram.Supervisi dapat mengembangkan dan meningkatkan profesionalisme guru sehingga guru tersebut dapat berkembang dengan pekerjaannya,sehingga dengan adanya supervisi pendidikan ini sangat meyakinkan seorang tenaga pendidik untuk bisa memajukan mutu pendidikan itu sendiri.Oleh karena itu,dalam meningkatkan mutu pendidikan kita harus tau apa yang menyebabkan mutu pendidikan itu rendah dan strategi pendekatan apa yang dipakai sehingga didapatkan suatu jalan keluar dari setiap permasalahan yang terjadi.

\section{SARAN}

Mutu pendidikan seharusnya dapat ditingkatkan lagi melalui strategi pendekatan dari supervisi pendidikan.Supervisi haruslah ada pada setiap lembaga sekolah agar nantinya proses pembelajaran mampu mendongkrak mutu dari pendidikan itu sendiri sehingga mengahasilkan generasi muda yang bermutu.

\section{REFERENSI}

Bahrun, marniati, R. syahputa. (2017). Strategi peningkatan mutu pendidikan pada SMA N 3 Meulaboh kecamatan johan pahlawan kabupaten aceh barat. Magister Administrasi Supervisi Pendidikan, 5(3), 161-166. Retrieved from http://jurnal.unsyiah.ac.id/JAP/article/viewFile/9024/7339

Bambang Ismanto. (n.d.). Peningkatan Mutu Pembelajaran Melalui Supervisi Akademik Berdasarkan Mutu Standar Proses Pembelajaran (Studi Kasus Pemetaan Mutu Pendidikan di Provinsi Jawa Tengah). Studi Kasus, 101-110. Retrieved from https://www.google.com/url?sa=t\&rct=j\&q=\&esrc=s\&source=web\&cd=3\&cad=rja\&uact=8\& ved=2ahUKEwiXyeqB1uLhAhVKQo8KHXM8AdEQFjACegQIBhAC\&url=http\%3A\%2F\%2 Fris.uksw.edu\%2Fdownload\%2Fmakalah\%2Fkode\%2FM02375\&usg=AOvVaw2w9cgcTgiXy nHJKQlcy1vF

Sabandi, A. (2013). Supervisi Pendidikan Untuk Pengembangan Profesionalitas Guru Berkelanjutan. Jurnal Ilmiah Ilmu Pendidikan, XIII(2), 1-9. Retrieved from http://ejournal.unp.ac.id/index.php/pedagogi/article/view/4275

Widodo, H. (2016). Potret Pendidikan Di Indonesia Dan Kesiapannya Dalam Menghadapi Masyarakat Ekonomi Asia (Mea). Cendekia: Journal of Education and Society, 13(2), 293. 
Makalah Supervisi Pendidikan

Meningkatkan Mutu Pendidikan Melalui Supervisi Pendidikan

Universitas Negeri Padang

21 April 2019

https://doi.org/10.21154/cendekia.v13i2.250 